\title{
ZAKAT PRODUKTIF SEBAGAI MODAL USAHA MASYARAKAT (STUDI BADAN AMIL ZAKAT KOTA BENGKULU)
}

\author{
Dwi Putra Jaya \\ Fakultas Hukum Universitas Dehasen \\ Jalan Meranti Raya Kota Bengkulu \\ Pos-el: dwiputrajaya@unived.ac.id \\ Hurairah \\ Fakultas Hukum Universitas Dehasen \\ Jalan Meranti Raya Kota Bengkulu \\ Pos-el: hurairahlatief@gmail.com
}

\begin{abstract}
The purpose of this research is clarity which can make it easy for Mustahiq (beneficiaries) to find business capital by borrowing capital at BAZNAS (The National Zakat Board) of Bengkulu City and the results of this study can be used as material for further study to produce legislation regarding the rights of Mustahiq in existing regulations. It is field research using qualitative descriptive methods. Descriptive research is to analyze the data that the author has obtained, the author uses a comparative analysis method, namely research that aims to systematically, factually, and accurately compare facts, situations or events in the field. From the results of research on the effectiveness of zakat funds received by the community, a total of eight asnaf (a Muslim person who is entitled to receive zakat and fitrah) received professional zakat assistance, those who are, fakir (a Muslim person who (a) has no property or income; or (b) has property or income but does not reach fifty per cent of the kifayah limit of himself and his dependants), poor, fisabilillah (the struggle, efforts and activities for the purpose of upholding and propagating the religion of Islam), mu'allaf (a call for individuals who are non-Muslims or non-Muslims who have the hope of converting to Islam or those who are new to Islam whose faith still needs to be supported and reinforced), and musafir (traveler), as well as productive zakat for small traders in advancing their business. The distribution of productive zakat given by BAZNAS of Bengkulu City through the "Program" to mustahik in the Bengkulu City area can improve two factors of Mustahik's welfare.
\end{abstract}

Keywords: productive zakat; mustahik.

\begin{abstract}
Abstrak: Tujuan penelitian kejelasan yang dapat menimbulkan Bagi mustahik akan mudah dalam mencari modal usaha dengan meminjam modal di BAZNAS kota Bengkulu dan Hasil penelitian ini dapat dijadikan bahan kajian lebih lanjut untuk melahirkan peraturan perundang-undangan tentang hak para Mustahik dalam peraturan yang ada di BAZNAS kota Bengkulu. Penelitian lapangan (field reseach) dengan menggunakan metode deskriptif kualitatif. Penelitian deskriptif untuk menganalisis data yang telah penulis peroleh, penulis menggunakan cara analisis komperatif yakni penelitian yang bertujuan membandingkan secara sistematis, faktual, dan akurat mengenai fakta-fakta, situasi atau kejadian yang ada di lapangan. Dari hasil penelitian dalam efektifitas dana zakat yang diterima masyarakat secara keseluruhan delapan asnaf mendapatkan bantuan zakat profesi, yang mendapatkannya fakir, miskin, fisabilillah, mu'allaf dan musafir, serta zakat produktif untuk pedagang kecil dalam memajukan usahanya. Distribusi zakat produktif yang diberikan oleh BAZNAS Kota Bengkulu melalui "Program" kepada mustahik di daerah Kota Bengkulu dapat meningkatkan dua faktor kesejahteraan Mustahik.
\end{abstract}

Kata kunci: zakat produktif; mustahik 
Dwi Putra Jaya dan Hurairah: Zakat Produktif Sebagai Modal Usaha Masyarakat (Studi Badan Amil Zakat Kota Bengkulu)

\section{A. Pendahuluan}

Zakat merupakan sumber dana potensial strategis bagi upaya membangun kesejahteraan umat. $^{1}$ Dalam Islam ada lima sendi (rukun) yang menjadi kualitas keislaman, dan itu merupakan cerminan dari hubungan manusia dalam takaran hubungan horizontal dan vertical. Sebagaimana disebutkan dalam sabda Rasulullah:

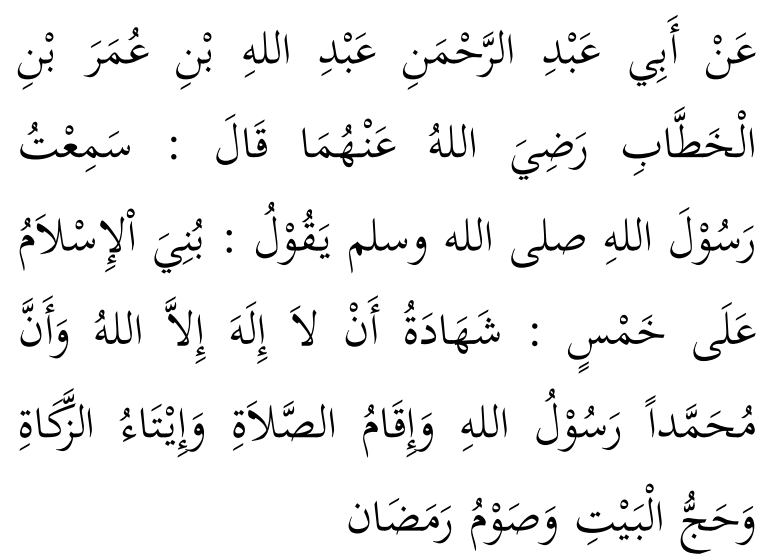

Artinya

Dari Ibn Umar, dari ayahnya berkata: Rasulullah SAW bersabda: "Islam dibangun atas lima perkara: Bersaksi bahwa tidak ada Tuhan selain Allah dan Muhammad adalah hamba dan utusan Allah, Mendirikan Shalat, Menunaikan Zakat, Melaksanakan Haji, dan Berpuasa di bulan Ramadhan".2

Dalam Al-Qur'an terdapat 27 ayat yang mengejajarkan kewajiban shalat dengan kewajiban zakat dalam berbagai bentuk. Di dalam Al-Qur'an terdapat pula berbagai ayat yang memuji orang-orang yang secara sungguh-sungguh menunaikannya dan sebaliknya memberikan

${ }^{1}$ Ahmad Rofiq, "Fiqih Kontekstual dari Normatif ke Pemaknaan Sosial”, (Yogyakarta: Pustaka Pelajar, 2004), h. 259

${ }^{2}$ Sahih muslim, juz 1, al-qana'ah, t.ter. h. 27 ancaman bagi orang- orang yang sengaja meninggalkannya. ${ }^{3}$ Sebagaimana firman Allah SWT dalam Surat Al-A'raf : 156

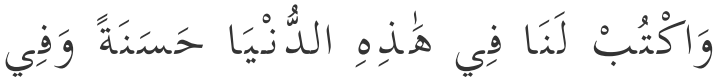

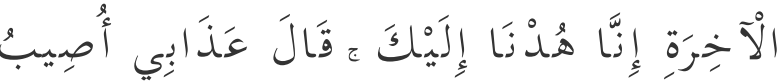

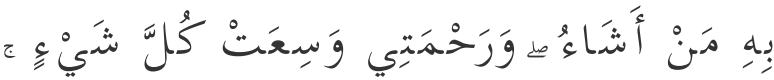

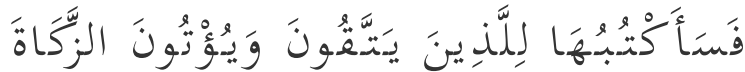

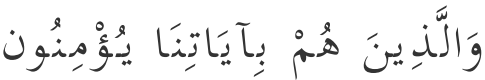

Artinya:

Dan tetapkanlah untuk kami kebajikan di dunia ini dan di akhirat; sesungguhnya kami kembali (bertaubat) kepada Engkau. Allah berfirman: "Siksa-Ku akan Kutimpakan kepada siapa yang Aku kehendaki dan rahmat-Ku meliputi segala sesuatu. Maka akan Aku tetapkan rahmatKu untuk orang-orang yang bertakwa, yang menunaikan zakat dan orang-orang yang beriman kepada ayat-ayat Kami.

Dalam Islam zakat merupakan suatu kewajiban yang dibebankan kepada orangorang yang mampu untuk diberikan kepada orang-orang yang berhak menerimanya. Zakat juga merupakan kewajiban yang persentase dan jumlahnya ditentukan, baik pemberi maupun penerima ${ }^{4}$. Ajaran Islam menjadikan ibadah yang mempunyai aspek sosial ini sebagai landasan membangun suatu sistem yang mampu mewujudkan kesejahteraan dunia dan akhirat. Tidak mengintegrasikannya dalam ibadah berarti

${ }^{3}$ Didin Hafiduddin, "Zakat dalam Perekonomian Modern”, (Jakarta: Gema Insani Press, 2002), h. 1

${ }^{4}$ Yusuf Qardhawi, "Kiat Islam Mengentaskan Kemiskinan", terj. Syahril Hakim, (Jakarta: Gema Insani Press, 1995), h. 100 
membisukan peranan penting pada keyakinan keimanan yang mengendalikan seorang mukmin dalam hidupnya. Demikianlah fungsi sesungguhnya dari ibadah yang dikenal dengan nama zakat. Dalam kelanjutannya peranan organisasi dan kekuasaan yang mengatur dan mengayomi masyarakat juga diikutsertakan, yaitu dengan adanya 'Amilin dan Imam atau Khalifah yang aktif dalam menjalankan dan mengatur pelaksanaan tersebut. Zakat bukanlah satu-satunya gambaran dari sistem yang ditampilkan oleh ajaran Islam dalam mewujudkan kesejahteraan umum bagi masyarakat. Namun harus diakui bahwa zakat sangat penting arti dan kedudukannya karena merupakan titik sentral dari sistem tersebut. $^{5}$

Jadi pelaksanaan zakat bukanlah semata-mata diserahkan kepada kesadaran muzakki, akan tetapi tanggungjawab memungut dan mendistribusikannya dilakukan oleh 'Amilin. ${ }^{6}$

Sebagaimana firman Allah SWT dalam Q.S At-Taubah : 103 Artinya :

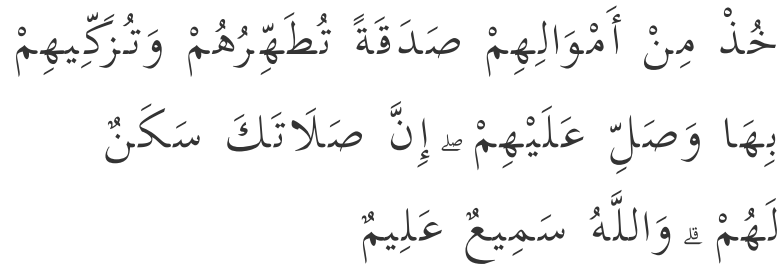

Artinya:

"Ambillah zakat dari sebagian harta mereka, dengan zakat itu kamu membersihkan dan mensucikan mereka dan mendoalah untuk mereka. Sesungguhnya doa kamu itu (menjadi) ketenteraman jiwa bagi mereka. Dan Allah Maha Mendengar lagi Maha Mengetahui"

Pembersihan dari najis-najis yang ada pada suatu barang, sedangkan barang itu tetap utuh. Sesuatu yang najis atau kotor telah disucikan, kuantitas barangnya tetap, sedang perkembangannya ialah bertambahnya kualitas barang tersebut.

Indonesia dengan masyarakat yang $80 \%$ beragama Islam memang menyimpan potensi Zakat yang besar. Logikanya, bila 220.953.634 juta jiwa penduduk Indonesia dan dari jumlah tersebut jumlah tersebut $80 \%$ beragama Islam. Katakanlah yang membayar zakat $1 \%$ saja dari seluruhnya maka bisa dihitung $1 / 100 \times$ x $80 / 100 \times$ 220.953 .634 jiwa $=1.767 .629$ jiwa. Apabila mereka tiap tahunnya membayar Zakat Rp.10.000,00 maka uang yang terkumpul sebanyak Rp. 17.676.290.000,00. Dana ini tentu saja akan besar manfaatnya bagi pembangunan manusia seutuhnya terutama untuk memberantas kekufuran, kemiskinan dan keterbelakangan. Belum lagi Zakat harta, perdagangan, profesi, pertanian, dan lain sebagainya. ${ }^{7}$

Angka-angka di atas barulah sekedar asumsi dan potensi yang belum menjadi sebuah kenyataan. Untuk menjadikannya

${ }^{7}$ Sumber: Departemen Dalam Negeri RI, Data Wilayah Administrasi Pemerintahan. Pdf http://id.wikipedia.org/wiki/Daftar Provinsi Indonesia menurut jumlah penduduk pada tahun 2015 di akses pada Tanggal 12 januari 2017 
kenyataan, tentu potensi Zakat tersebut harus digali, direspon dan diupayakan oleh pemerintah bersama masyarakat, terutama Badan Pengelola Zakat (BPZ), baik oleh Badan Amil Zakat (BAZ) ataupum Lembaga Amil Zakat (LAZ). Sebab, apabila hal tersebut tidak digali, direspon dan diupayakan keberadaannya, maka hal itu hanya menjadi potensi tanpa bentuk dan tak akan bermakna apa-apa.

Angka kemiskinan dari hari ke hari di Indonesia grafiknya semakin meningkat. Apalagi krisis multidimensi yang melanda bangsa Indonesia dari pertengahan tahun 1997 sampai saat ini belum berakhir. Masalah kemiskinan memang tanggung jawab negara. ${ }^{8}$ Namun dengan melihat kondisi tersebut, potensi dana Zakat yang besar tersebut dapat berperan membantu pemerintah dalam mengatasi kemiskinan dan kesenjangan ekonomi,

Zakat juga sebagai faktor yang sangat signifikan dalam proses pengentasan kemiskinan. Dengan zakat akan terwujud keseimbangan dalam distribusi harta dan kepemilikan, sehingga harta tersebut tidak hanya dikuasai oleh orang-orang kaya saja. Satu bukti bahwa Zakat belum diberdayakan dengan baik, dapat dilihat dari kondisi masyarakat Islam yang sebagian besar masuk dalam kategori fakir miskin. Bahkan pengambilan dana untuk pembangunan panti asuhan, sekolah serta tempat-tempat ibadah

\footnotetext{
${ }^{8}$ Pasal 34 UUD 1945
}

seperti yang ada di perempatan jalan atau di angkutan umum (bus) mayoritas berasal dari umat Islam, dan kenyataan ini ada hampir di seluruh wilayah Nusantara, termasuk di kabupaten Magelang sendiri.

Di Indonesia, pendistribusian zakat selama ini melalui dua kategori, yaitu kategori konsumtif dan produktif. ${ }^{9}$ Sebenarnya bila kita perhatikan keadaan fakir miskin, maka tetap ada Zakat konsumtif bagi mereka yang sudah tidak mampu dalam segala hal, seperti anak-anak yatim yang belum bisa berusaha, orangorang jompo, orang-orang cacat, sehingga dengan keadaan seperti ini tidak bisa dihindari. Tetapi bagi yang masih kuat dalam bekerja dan mandiri dalam menjalankan usaha baik itu diberikan secara hibah maupun dalam bentuk pinjaman. ${ }^{10}$

BAZNAS kota Bengkulu telah melaksanakan pembagian zakat kepada masyarakat sebagai modal usaha dengan memberikan zakat yang tujuannya adalah supaya zakat tersebut dapat berkembang sehingga tujuan zakat dapat tercapai.

Pemberian modal usaha yang diambil dari dana zakat tidak akan dapat efektif jika tidak dapat mengukur secara akurat tingkat pencapaian keberhasilan. Mengukur secara akurat ini penting sebab

${ }^{9}$ Didin Hafiduddin, "Zakat Dalam Perekonomian Modern", (Jakarta: Gema Insani, 2002), h. 133

${ }^{10}$ M. Ali Hasan, (Zakat Pajak Asuransi dan Lembaga Keuangan), (Jakarta: Raja Grafindo Persada, 1996), h. 23 
BAZNAS dapat membantu mustahik secara efektif jika tidak mengetahui pengetahuan dan keterampilan yang dikuasai setiap mustahiknya dan kekurangan apa yang masih menjadi masalah bagi mustahik. Hal yang sama pentingnya adalah BAZNAS tidak dapat memperbaiki jika tidak memperoleh indikasi efektifitas dalam memberikan zakat sebagai modal usaha.

Efektifitas dapat diartikan mengukur dan menggambarkan pengetahuan dan ketrampilan mustahik atau sebagai dasar untuk mengambil keputusan. Alasan mengapa mengukur pencapaian: adalah sebagai umpan balik yang merupakan fungsi penting pada mengukur pencapaian. Atau dengan kata lain adalah memberikan umpan balik dengan mempertimbangkan efektifitas pemberian modal usaha. Pengetahuan pada performance mustahik membantu muzakki /BAZNAS untuk mengevaluasi pembelajaran mereka dengan menunjuk area dimana pemberian modal usaha telah efektif dan area dimana mustahik belum dapat meggunakan pemberian dana zakat sebagi modal usaha. Informasi ini dapat digunakan untuk merencanakan pendistribusian zakat sebagai modal usaha selanjutnya dan memberikan nasehat untuk metode pendayagunaan zakat alternatif.

Berangkat dari paparan ini, penulis beranggapan bahwa pembicaraan mengenai pendayagunaan zakat sebagai modal usaha sangat penting untuk dibahas baik dalam tataran konsep maupun prakteknya. Penulis mencoba untuk meneliti lebih lanjut tentang pemberian Zakat sebagai modal usaha di BAZNAS kota Bengkulu, karena di BAZNAS kota Bengkulu sendiri menerapkan pemberian zakat sebagai modal usaha dalam bentuk pinjaman.

Dari uraian tersebut diatas penulis sangat tertarik untuk meneliti lebih lanjut dan detail terhadap muzaki sehingga menumbuhkan sikap sadar yang tinggi. Selain itu praktek dalam pendayagunaan zakat sebagai modal usaha sudah tercapai apa belum, dengan tujuan hasil dari zakat tersebut benar-benar dapat dirasakan oleh masyarakat Bengkulu. Penulis akan membahas permasalahan ini dalam bentuk sebuah proposal dengan judul Zakat Produktif Sebagai Modal Usaha Masyarakat Stadi Badan Amil Zakat Kota Bengkulu.

\section{B. Rumusan Masalah}

Berdasarkan atas pembatasan masalah yang dilakukan oleh peneliti, maka rumusan masalah yang ada dalam penelitian ini adalah :

1. Bagaimana Zakat Produktif Sebagai Modal Usaha Masyarakat Stadi Badan Amil Zakat Kota Bengkulu?

2. Bagaimana Penerapan Zakat Produktif Sebagai Modal Usaha Masyarakat Stadi Badan Amil Zakat Kota Bengkulu? 


\section{Metode Penelitian}

Jenis penelitan dan pendekatan Penelitian lapangan (field reseach) dengan menggunakan metode deskristif kualitatif. Penelitian deskriptif untuk menganalisis data yang telah penulis peroleh, penulis menggunakan cara analisis komperatif yakni penelitian yang bertujuan membandingkan secara sistematis, faktual, dan akurat mengenai fakta-fakta, situasi atau kejadian yang ada di lapangan.

\section{Efektivitas}

Kurniawan menjelaskan jika efektivitas merupakan kemampuan melaksanakan tugas, fungsi (operasi kegiatan program atau misi) dari pada suat organisasi atau sejenisnya yang tidak adanya tekanan atau ketegangan diantar pelaksanaannya. ${ }^{11}$ Pengertian tersebut mengartikan bahwa efektivitas merupaka tahap dicapainya keberhasilan dalam mencapai tujuan yang telah ditetapkan Efektivitas selalu terkait dengan hubungan antara hasil yang diharapkan denga hasil yang sesungguhnya dicapai. Berbeda dengan pendapat Susanto, yan memberikan definisi tentang Efektivitas merupakan daya pesan untu mempengaruhi atau tingkat kemampuan pesan-pesan untuk mempengaruhi. Jad dapat diartikan jika efektifitas sebagai suatu pengukuran akan

\footnotetext{
${ }^{11}$ http://ejournal.uajy.ac.id/4241/3/2MH01723.p df. Diakses pada 13 mei 2019 pulu 02.00 WIB

tercapainya tujua yang telah direncanakan sebelumnya secara matang. Efektivitas juga dapat diartikan sebagai ukuran berhasil tidaknya suat organisasi mencapai tujuannya. Apabila suatu organisasi berhasil mencapai tujuannya, maka organisasi tersebut dikatakan telah berjalan dengan efektif. ${ }^{12}$

Menurut Bastian efektivitas dapat diartikan sebagai keberhasilan dalam mencapai tujuan yang telah ditetapkan sebelumnya. Selain itu efektifitas adalah hubungan antara output dan tujuan dimana efektivitas diukur berdasarkan seberapa jauh tingkat output atau keluaran kebijakan untuk mencapai tujuan yang telah ditetapkan. Selanjutnya istilah efektivitas adalah pencapaian tujuan ata hasil yang dikehendaki tanpa menghiraukan faktor-faktor tenaga, waktu, biaya pikiran, alat-alat dan lain-lain yang telah ditentukan. ${ }^{13}$

Effendy menjelaskan efektivitas adalah komunikasi yang prosesny mencapai tujuan yang direncanakan sesuai dengan biaya yang dianggarkan, wakt yang ditetapkan dan jumlah personil yang ditentukan. ${ }^{14}$ Jadi dapat diartika bahwa indikator efektivitas dalam arti tercapainya

${ }^{12}$ Ulum. Ihyaul MD, 2004, Akuntansi Sektor Publik, Malang,UMM Press, H. 294.

${ }^{13} \mathrm{http}$ ///ejournal.uajy.ac.id/4241/3/2MH01723.p df. Diakses pada 13 mei 2019 pukul 02.00 WIB

${ }^{14}$ Asnawi. 2013, Efektivitas Penyelenggaraan Publik Pada Samsat Corner Wilayah Malang Kota, Skripsi S-1 Jurusan Ilmu Pemerintahan, FISIP, UMM, h.6 
sasaran atau tujuan yang tela ditentukan sebelumnya merupakan sebuah pengukuran dimana suatu target tela tercapai sesuai dengan apa yang telah direncanakan.

Memperhatikan pendapat para ahli di atas, dapat disimpulkan bahw efektivitas adalah suatu keadaan yang terjadi sebagai akibat dari apa yan dikehendaki. Misalkan saja jika seseorang melakukan suatu perbuatan denga maksud tertentu dan memang dikehendakinya, maka perbuatan orang itu dikatakan efektiv jika hasil yang dicapai sesuai dengan apa yang dikehendakiny dan telah direncanakan sebelumnya.

\section{E. Zakat Produktif}

Definisi zakat produktif akan menjadi lebih mudah dipahami jika diartikan berdasarkan suku kata yang membentuknya. Zakat adalah isim masdar dari kata zakayazku-zakah oleh karena kata dasar zakat adalah zaka yang berarti berkah, tumbuh, bersih, baik, dan berkembang. ${ }^{15}$

Sedangkan kata produktif adala berasal dari bahasa inggris yaitu "produktive" yang berarti menghasilkan atau memberikan banyak hasil. ${ }^{16}$

Jadi dapat disimpulkan bahwa zakat produktif adalah pemberian zakat yang

${ }^{15}$ Fahruddin, Fiqh dan Manajemen Zakat Indonesia, Malang: UIN Malang Press, 2008, cet-1, h. 13

${ }^{16}$ Joyce M. Hawkins, Kamus Dwi Bahasa Inggris- Indonesia, Indonesia-Inggris, Exford: Erlangga,1996, h.267 dapat membuat para penerimanya menghasilkan sesuatu secara terus menerus dengan harta zakat yang telah diterimanya. Zakat produktif dengan demikian adalah zakat dimana harta atau dana zakat yang diberikan kepada para mustahik tidak dihabiskan, akan tetapi dikembangkan dan digunakan untuk membantu usaha mereka, sehingga dengan usaha tersebut mereka dapat memenuhi kebutuhan hidup secara terus menerus. Sehingga dapat disimpulkan bahwa zakat produktif adalah zakat yang dikelola dengan cara produktif, yang dilakukan dengan cara pemberian modal kepada para penerima zakat dan kemudian dikembangkan, untuk memenuhi kebutuhan hidup mereka untuk masa yang akan datang. ${ }^{17}$

Yusuf Qardhawi berpendapat bahwa menunaikanzakat termasuk amal ibadah sosial dalam rangka membantu orang-orang miskin dan golongan ekonomi lemah untuk menjunjung ekonomi mereka sehingga mampu berdiri sendiri dimasa mendatang dan tabah dalam mempertahankan kewajiban-kewajibannya kepada Allah. ${ }^{18}$

Saefudin menyetujui cara pembagian zakat produktif, dengan menciptakan pekerjaan berarti 'amil dalam hal ini pemerintah dapat menciptaan

${ }^{17}$ Asnainu, S.Ag, M.ag, Zakat Produktif dalam Persfektif Hukum Islam, Yogyakarta: Pustaka Pelajar, 2008, cetakan ke-1, h.64

${ }^{18}$ Yusuf Qadhawi, Musykilah al-Faqr Wakaifa Aalajaha Al Islam, Beirut:1966, h.12 
Dwi Putra Jaya dan Hurairah: Zakat Produktif Sebagai Modal Usaha Masyarakat (Studi Badan Amil Zakat Kota Bengkulu)

lapangan pekerjaan dengan dana zakat,seperti perusahaan, modal usaha atau beasiswa, agar mereka memiliki suatu usaha yang tetap dan ketrampilan serta ilmu untuk menopang hidup kearah yang lebih baik dan layak.

Penyaluran zakat secara produktif ini pernah terjadi di zaman Rasulullah SAW. Dikemukakan dalam sebuah hadits riwayat Imam Muslim dari Salim Bin Abdillah Bin Umar dari ayahnya, bahwa Rasulullah telah memberikan zakat kepadanya lalu menyuruhnya untuk dikembangkan atau disedekahkan lagi.

Disyaratkan bahwa yang berhak memberikat zakat yang bersifat produktif adalah yang mampu melakukan pembinaan dan pendampingan kepada para mustahik agar kegiatan usahanya dapat berjalan dengan baik. Di samping melakukan pembinaan dan pendampingan kepada para mustahik dalam kegiatan usahanya, juga harus memberikan pembinaan ruhani dan intelektual keagamaannya agar semakin meningkat kualitas keimanan dan keislamanannya.

Dari bebrapa pendapat diatas dapat disimpulkan bahwa zakat roduktif adalah boleh bahkan sangat dianjurkan bila dikaitkan dengan situasi dan kondisi negara indonesia saat ini. Agar dari zakat produktif tersebut, masyarakat bisa berorientasi dan berbudaya produktif, sehingga dapat memproduksi sesuatu yang dapat menjamin kebutuhan hidup mereka. ${ }^{19}$

\section{Dasar Hukum Zakat Produktif}

Dalam Al-Qur'an, Hadits dan Ijma' tidak menyebutkan secara tegas dan rinci mengenai dalil zakat produktif, akan tetapi ada celah dimana zakat dapat di kembangkan. Seperti dalam hadits yang diriwayatkan oleh Muslim yang mana Artinya: 'Ambilah dahulu, setelah itu milikilah (berdayakanlah) dan sedekahkan kepada orang lain dan apa yang datang kepadamu dari harta semacam ini sedang engkau tidak membutukannya dan bukan engkau minta, maka ambilah. Dan manamana yang tidak demikian maka janganlah engkau turutkan nafsumu'”. HR Muslim. ${ }^{20}$

Hadits di atas menyebutkan bahwa pemberian harta zakat dapat diberdayakan atau diproduktifkan. Teori hukum Islam menunjukkan bahwa dalam menghadapi masalah-masalah yang tidak jelas rinciannya dalam Al-Quran atau petunjuk yang ditinggalkan Nabi SAW, penyelesaiannya adalah dengan metode ijtihad. Ijtihad atau pemakaian akal dengan tetap berpedoman pada al-Quran dan Hadits.

Dengan demikian berarti bahwa teknik pelaksanaan pembagian zakat bukan sesuatu yang mutlak, akan tetapi dinamis, sapat disesuaikan dengan kebutuhan di

19 Asnainu, Zakat Produktif dalam Persfektif Hukum Islam, Bengkulu:Pustaka Pelajar, 2008, cetakan ke-1, h.93

20 Abu Bakar Muhammad (Penerjemah) Terjemahan Subulus Salam II. h. 588 
suatu tempat. Dalam artian perubahan dan perbedaan dalam cara pembagian zakat tidaklah dilarang dalam islam karena tidak ada dasar hukum yang secara jelas menyebutkan cara pembagian zakat tersebut. ${ }^{21}$

\section{Jenis Harta Zakat Produktif}

Dalam kajian sejarah, ditemukan beberapa indikasi bahwa memang zakat sebaiknya tidak hanya dikelola secara konsumtif, tetapi dapat didayagunakan menjadi produktif. Adapun indikator yang kami maksud tersebut adalah :

a. Rasulullah SAW tidak memberikan gaji resmi kepada para pengumpul zakat.

b. Kebijakan Abu Bakar As-Siddiq yang tidak menahan harta negara terlalu lama, termasuk harta zakat yang dikumpulkan.

c. Pada pemerintahan Gubernur Syria diberlakukannya zakat atas kuda dan budak.

d. Khalifah Umar memberlakukan zakat atas kebun karet yang ditemukan di semenanjung Yaman, hasil- hasil laut serta madu.

e. Khalifah Utsman ibnu Affan mendelegasikan kewenangan menaksir harta yang dizakati kepada para pemiliknya masing-masing.

f. Gubernur Kuffah atas izin Khalifah Ali bin Abi Thalib memungut zakat

${ }^{21}$ Abu Bakar Muhammad...h. 86 atas sayuran segar yang akan digunakan sebagai bumbu masakan. ${ }^{22}$

\section{Syarat dan Rukun Zakat}

Adapun syarat dan rukun zakat produktif sama dengan syarat dan rukun pada zakat pada umumnya. Diantara syarat wajib zakat yakni kefardluannya bagi seorang muzakki adalah:

a. Merdeka, yaitu zakat dikenakan kepada orang- orang yang dapat bertindak bebas, menurut kesepakatan para ulama zakat tidak wajib atas hamba sahaya yang tidak mempunyai milik. Karena zakat pada hakikatnya hanya diwajibkan pada harta yang dimiliki secara penuh.

b. Islam, menurut Ijma', zakat tidak wajib atas orang-orang kafir karena zakat ini merupakan ibadah mahdah yang suci sedangkan orang kafir bukan orang suci.

c. Baligh dan Berakal. Zakat tidak wajib diambil atas harta anak kecil dan orang-orang gila sebab keduanya tidak termasuk ke dalam ketentuan orang yang wajib mengeluarkan ibadah seperti sholat dan puasa.

d. Harta yang dikeluarkan adalah harta yang wajib dizakati, diisyaratkan produktif dan berkembang sebab salah satu makna zakat adalah berkembang dan produktifitas yang dihasilkan

22 Azwar Karim, Sejarah Pemikiran Ekonomi Islam, Jakarta: PT. Raja Grafindo Persada,2004, h. 22 
Dwi Putra Jaya dan Hurairah: Zakat Produktif Sebagai Modal Usaha Masyarakat (Studi Badan Amil Zakat Kota Bengkulu)

dari barang yang produktif.

e. Harta yang dizakati telah mencapai nishab atau senilai dengannya, ${ }^{23}$ maksudnya ialah nishab yang ditentukan oleh syara’ sebagai pertanda kayanya seseorang dan kadar-kadar yang mewajibkan berzakat.

f. Harta yang dizakati adalah milik penuh. Madzhab Hanafi berpendapat bahwa harta benda yang wajib dizakati adalah harta benda.

g. ditangan sendiri atau harta milik yang hak pengeluarannya berada ditangan seseorang atau harta yang dimiliki secara asli.

h. Kepemilikan harta telah mencapai setahun atau telah sampai jangka waktu yang mewajibkan seseorang mengeluarkan zakat misal pada masa panen.

i. I Harta tersebut bukan merupakan harta hasil utang.

Adapun rukun zakat adalah mengeluarkan sebagian dari nishab (harta), dengan melepaskan kepemilikan terhadapnya, menjadikannya sebagaimilik orang fakir, dan menyerahkannya kepadanya atau harta tersebutdiserahkan kepada amil zakat. Dari penjelasan tersebut maka rukun zakatdapat diperinci sebagai berikut :

a. Adanya muzakki

23 Muhammad Daud ali, Sistem Ekonomi Islam; Zakat dan Wakaf, Jakarta: Universitas Indonesia, 1988, h. 41 b. Adanya mustahik

c. Adanya harta yang mencapai nishab

d. Adanya $a m i l^{24}$

\section{Mustahik Zakat}

Bicara sistem pendayagunaan dana zakat berarti membicarakan beberapa usaha atau kegiatan yang saling berkaitan dalam menciptakan tujuan tertentu dari penggunaan hasil zakat secara baik, tepat dan terarah sesuai dengan tujuan zakat itu disyariatkan. Dalam pendekatan fikih, dasar pendayagunaan zakat umumnya didasarkan pada QS. At-taubah ayat 60 sebagai berikut: ${ }^{25}$

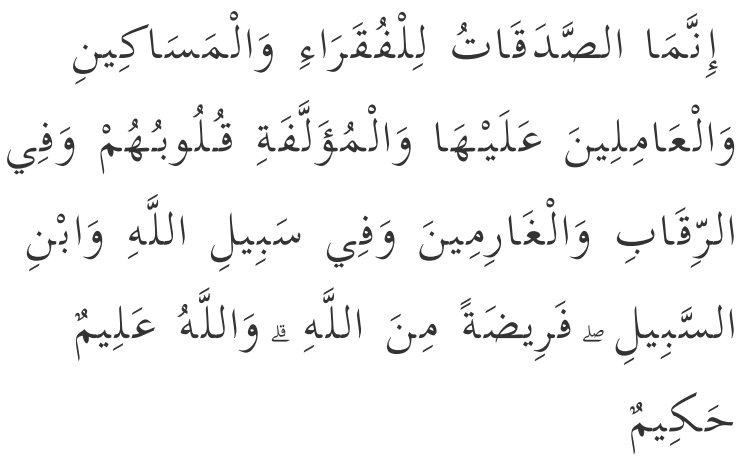

Artinya

Sesungguhnya zakat-zakat itu, hanyalah untuk orang-orang fakir, orangorang miskin, pengurus-pengurus zakat, Para mu'allaf yang dibujuk hatinya, untuk (memerdekakan) budak, orang-orang yang berhutang, untuk jalan Allah dan untuk mereka yuang sedang dalam perjalanan, sebagai suatu ketetapan yang diwajibkan Allah, dan Allah Maha mengetahui lagi Maha Bijaksana

Ayat ini menjelaskan tentang peruntuk-an kepada siapa zakat itu

${ }^{24}$ Terjemahan dari Wahbah Al-Zuhaili, Zakat kajian Berbagai Madzhab, Bandung: Remaja Rosda Karya cet ke 6, 2005, h. 111

${ }^{25}$ Departemen Agama RI...h. 197 
diberikan. Para ahli tafsir menguraikan kedudukan ayat tersebut dalam uraian yang beragam, baik terhadap kuantitas, kualitas dan prioritas. ${ }^{26}$

Mustahiq zakat maksutnya adalah orang-orang yang berhak menerima zakat. Golongan yang berhak mendapatkan zakat pada tataran aplikasi dibatasi pada yang sudah disebutkan dalam QS AtTaubah ayat 60. Berdasarkan QS AtTaubah ayat 60 , mustahik zakat ada delapan golongan adalah sebagai berikut:

a. Fakir. Menurut Imam Syafi'i yakni orang yang tidak mempunyai harta dan tidak mempunyai mata pencaharian yang mana hal ini dialami secara terus menerus atau dalam beberapa waktu saja, baik dia meminta-minta maupun tidak.

b. Miskin. Adalah orang-orang yang memiliki harta namun tidak mencukupi untuk kebutuhan dasar hidupnya, sehingga tidak mencukupi kebutuhan sandang, pangan, dan papannya.

c. Amil. Adalah para pekerja yang telah diserahi oleh penguasa atau penggantinya untuk mengurusi harta zakat. Mereka diberi zakat, walaupun orang kaya sebagai imbalan jerih payahnya dalam membantu kelancaran zakat, karena mereka telah

26 Ilyas Supena dan Darmuin, Manajemen Zakat, Semarang: Walisongo Press, 2009, h. 31-31 mencurahkan tenaganya untuk kepentingan orang-orang islam.

d. Muallaf. Muallaf pada umumnya dipahami dengan orang yang baru masuk Islam. Secara historis, pada masa awal Islam, muallaf yang diberikan dana zakat dibagi kepada dua kelompok, yaitu:

1. Orang kafir yang diharapkan dapat masuk Islam.

2. Orang Islam, terdiri dariu pemuka muslim yang disegani oleh orang kafir, muslim yang masih lemah imannya agar dapat konsisten pada keimanannya, dan muslim yang berada di daerah musuh.

e. Riqab. Menurut Imam Syafi'i riqab adalah hamba sahaya yang sedang dalam proses memerdekakan dirinya atau yang diistilahkan dengan mukatib.

f. Gharim. Gharim adalah orang yang berhutang, baik untuk kepentingan diri sendiri maupun untuk kepentingan orang lain. Orang yang jatuh pailit atau orang yang punya pinjaman modal untuk usaha kecil termasuk dalam kategori gharim.

g. Fisabilillah. Secara harfiah, fisabilillah berarti jalan Allah. Menurut Yusuf Qardhawi, segala perbuatan yang menimbulkan kemaslahatan dan mendekatkan diri kepada Allah.

h. Ibnu Sabil.Secara harfiah berarti anak jalanan. Namun anak jalanan dalam 
Dwi Putra Jaya dan Hurairah: Zakat Produktif Sebagai Modal Usaha Masyarakat (Studi Badan Amil Zakat Kota Bengkulu)

pengertian anak-anak yang berada di jalan dan tidak memliki tempat tinggal sehingga hampir sepanjang hari berada di jalan, mereka tidak termasuk dalam kelompok ini. Ulama terdahulu memahami ibnu sabil dalam arti siapapun yang kehabisan bekal dalam perjalanan walaupun dia kaya di negeri asalnya.

\section{Macam-Macam Zakat}

Dalam penyaluran zakat poduktif ada dua macam yaitu zakat produktif tradisional dan produktif kreatif, guna untuk melepaskan fakir miskin kepada taraf hidup yang layak dan dapat memenuhi semua kebutuhannya, yaitu kategori ketiga, zakat produktif tradisional adalah zakat yang diberikan dalam bentuk barang-barang produktif. Misalnya kambing, sapi, mesin jahit, alat-alat pertukaran dan sebagainya. Pemberian zakat dalam bentuk ini akan dapat mendorong orang menciptakan suatu usaha atau memberikan lapangan kerja bagi fakir miskin.

Kategori terakhir yaitu zakat produktif kreatif dimaksudkan semua pendayagunaan zakat yang diwujudkan dalam bentuk modal yang dapat dipergunakan, biak untuk membangun suatu proyek sosial maupun untuk membantu atau menambah modal seseorang pedagang atau pengusaha kecil. ${ }^{27}$

27 Asnaini, S.Ag, M.ag, Zakat Produktif dalam Persfektif Hukum Islam, Yogyakarta: Pustaka
Dari pembagian macam-macam zakat produktif diharapkan arah dan kebijaksanaan pengelolaan zakat produktif dapat berhasil sesuai dengan sasaran yang dituju. Adapun maksud arah dan kebijaksanaan pengelolaan zakat adalah segala sesuatu yang berkaitan dengan usaha pemerintah atau pengelola dalam rangka memanfaatkan hasil- hasil pengumpulan zakat kepada sasaran dalam pengertian yang lebih luas sesuai dengan cita dan rasa syara', secara tepat guna, efektif manfaatnya dengan sistem distribusi yang serba guna dan produktif sesuai dengan pesan dan kesan syari'at serta tujuan sosial ekonomi dari zakat.

Beberapa ulama modern dan ilmuwan telah mencoba menginterpretasikan pendayagunaan zakat dalam perspektif yang lebih luas mencakup edukatif, produktif, dan ekonomis. Dalam kehidupan sosial sekarang, pengelolaan dan penyaluran zakat untuk penduduk miskin harus mencakup:

a. Pembangunan prasarana dan sarana pertanian sebagai tumpuan kesejahteraan ekonomi rakyat, dalam pengertian yang luas,Pembangunan sektor industri yang secara langsung berorientasi pada peningkatan kesejahteraan rakyat banyak.

b. Penyelenggaraan sentra-sentra pendidikan ketrampilan dan kejuruan 
untuk mengatasi pengangguran.

c. Pemberian modal usaha kepada mustahik sebagai langkah awal mendirikan usaha,

d. Jaminan hidup orang-orang invalid, jompo, yatim piatu, dan orang-orang yang tidak punya pekerjaan.

e. Pengadaan sarana dan prasarana kesehatan bagi setiap warga atau rakyat yang membutuhkan, dan

f. Pengadaan sarana dan prasarana yang erat hubungannya dengan usaha mensejahterakan rakyat lapisan bawah. $^{28}$

\section{i. Hikmah dan Manfaat Zakat}

Kewajiban atau kefardhuan zakat merupakan jalan yang paling utama untuk menyelesaikan kesejangan sosial. Disamping itu, zakat merupakan formula yang paling kuat untuk merealisasikan sifat gotong-royong dan tanggung jawab sosial dikalangan umat Islam.

Tujuan tersebut mempunyai hikmah yang utama yaitu agar manusia lebih tinggi nilainya daripada harta, sehingga ia menjadi tuannya harta bukan menjadi budaknya harta. Karena, tujuan zakat terhadap si pemberi sama dengan tujuan terhadap si penerima.

Hikmah zakat ada 2 (dua) macam yaitu hikmah bagi si pemberi dan hikmah

28 M. Arif Mufraini, Akuntansi dan Manajemen Zakat, Jakarta: Kencana Prenada Media Group, 2006, h. 106-111 bagi si penerima.

Adapun hikmah zakat bagi si pemberi antar lain:

1. Mensucikan jiwa dari sifat kikir. Sifat kikir merupakan tabiat manusia yang tercela, sifat ini timbul karena rasa keinginan untuk memiliki sesuatu sehingga manusia cenderung mementingkan diri sendiri terhadap hal-hal yang baik dan bermanfaat dari pada orang lain.

2. Merupakan manifestasi syukur atas nikmat Allah. Karena sesungguhnya Allah SWT senantiasa memberikan nikmat kepada hambanya baik yang berhubungan dengan diri maupun hartanya.

3. Mengembangkan kekayaan batin. Dengan mengeluarkan zakat berarti telah berusaha menghilangkan kelemahan jiwanya, egoisme serta menghilangkan bujukan setan dan hawa nafsu.

Hikmah bagi si penerima sebagai berikut:

a. Membebaskan si penerima sari kebutuhan. Allah SWT telah mewajibkan zakat dan menjadikannya tiang agama dalam Islam, dimana zakat diambil dari orangorang kaya dan diberikan kepada orang-orang fakir, dengan adanya zakat tersebut mereka dapat memenuhi kebutuhan materinya. 
b. Menghilangkan sifat benci dan dengki. Atas dasar diperintahkan wajib zakat, orang akan merasa baha muslim yang satu bersaudara dengan muslim yang lain, sehingga tidak ada rasa dendam, dengki dan benci.

Zakat sebagai salah satu perangkat sosio-ekonomi Islam yang tidak saja bernilai ibadah juga bersifat sosial. Sebagaimana syari'at Islam yang lainnya, zakat juga memiliki beberapa tujuan mulia antara lain:

1. Mewujudkan keadilan dan pemerataan ekonomi. Zakat bertujuan untuk mengurangi jurang perbedaan dan kesenjangan antara yang kaya dan miskin sehingga tercipta pemerataan ekonomi dan keadilan.

2. Mengikis kemiskinan dan kecemburuan sosial. Jika zakat secara konsisten dapat direalisasikan, maka akan tercipta masyarakat yang jauh dari sifat-sifat kecemburuan sosial yang muncul manakala kemiskinan menghimpit seseorang sedangkan disekelilingnya orang hidup berkecukupan tetapi sama sekali tidak peduli. $^{29}$

\section{ii. Sistem Pengelolaan Zakat Produktif}

Secara umum lembaga pengelola zakat didasarkan atas perintah Allah (QS.

29 El-Madani, Fiqh Zakat Lengkap, Yogyakarta: Diva Press, 2013, h. 13
At-Taubah: 60) yang menyebutkan katakata "wal amilina alaiha", artinya pengurus-pengurus zakat, yang lebih dikenal dengan amil zakat adalah mereka yang melaksanakan segala kegiatan urusan zakat, mulai dari para pengumpul sampai kepada bendahara dan para penjaganya, juga mulai dari pencatat sampai kepada penghitung yang mencatat keluar masuk zakat, dan membagi kepada para mustahiknya.

Sebuah pendistribusian zakat dilakukan untuk mencapai visi zakat yaitu menciptakan masyarakat muslim yang kokoh baik dalam bidang ekonomi maupun non ekonomi. Untuk mencapai visi tersebut diperlukan misi distribusi zakat yang memadai. Misi yang diharapkan bersifat produktif yakni mengalokasikan zakat kepada mustahiq, dengan harapan langsung menimbulkan muzakki-muzakki baru.Dan tentunya dalam sistem alokasi zakat tersebut harus mencapai kriteria sebagai berikut:

1. Prosedur alokasi zakat yang mencerminkan pengendalian yang memadai sebagai indikator praktek yang adil.

2. Sistem seleksi mustahiq dan penetapan kadar zakat yang dialokasikankepada kelompok mustahiq.

3. Sistem informasi muzakki dan mustahiq (SIMM).

4. Sistem dokumentasi dan pelaporan 
yang memadai.

Dari empat hal tersebut harus dirancang sedemikian rupa sehingga hasil yang diharapkan dapat tercapai dan prinsip akuntabilitas dapat dipenuhi. Konsep ini jika diterapkan dengan baik akan dapat melihat potensi zakat dan dapat memprediksi perolehan zakat untuk suatu wilayah. Selanjutnya dalam pelaksanaan ibadah zakat sesuai dengan ketentuan agama, maka mutlak diperlukan pengelolaan (manajemen) zakat yang baik, benar dan profesional. ${ }^{30}$

Di Indonesia pengelolaan zakat diatur berdasarkan Undang-Undang No. 23 Tahun 2011 tentang pengelolaan zakat dimana pengertian, asas, dan tujuan pengelolaan zakat adalah sebagai berikut:

a. Pengertian pengelolaan zakat adalah kegiatan perencanaan, pelaksanaan, dan pengoordinasian dalam pengumpulan, pendistribusian, dan pendayagunaan zakat (pasal 1 angka 1).

b. Pengelolaan zakat berasaskan syariat Islam, amanah, kemanfaatan, keadilan, kepastian hukum, terintegrasi, dan akuntabilitas (pasal 2).

c. Pengelolaan zakat bertujuan meningkatkan efektifitas dan efisiensi pelayanan dalam pengelolaan zakat, serta meningkatkan manfaat zakat

30 Mursyidi, Akuntansi Zakat Kontemporer", Bandung : PT. Remaja Rosda Karya, 2003,h. 178180 untuk mewujudkan kesejahteraan masyarakat dan penanggulangan kemiskinan (pasal 3). ${ }^{31}$

Keberhasilan zakat tergantung kepada pengelolaan yang mampu bersifat daya guna bagi mustahik. Zakat harus diberikan kepada yang berhak (mustahik) yang sudah ditentukan menurut agama, penyerahan yang benar adalah melalui badan amil zakat. Pengelolaan yang tepat ialah yang sesuai dengan tujuan dan jatuh pada yang berhak (sesuai dengan nash) secara tepat guna. Ada beberapa proses dalam aktifitas manajemen pengelolaan zakat yang telah digariskan Islam dan telah dipraktekkan oleh Rasulullah SAW dan penerusnya, yakni para sahabat.

Proses tersebut meliputi penghimpunan atau pengumpulan, proses pertama ini dilakukan oleh para petugas zakat yang atau dalam Islam disebut dengan amil. Adapun tugas dari lembaga amil antara lain:

a. Pendataan para wajib zakat (muzakki).

b. Menentukan bentuk wajib zakat dan besarnya zakat yang harus dikeluarkan.

c. Penagihan zakat para muzakki.

Pekerjaan ini memerlukan manajemen meliputi planning, organizing, directing and controlling.

1. Planning (perencanaan) adalah pemilihan sekumpulan kegiatan dan pemutusan selanjutnya apa yang harus 
dilakukan, kapan, bagaimana, dan oleh siapa. Perencanaan yang baik dapat dicapai dengan mempertimbangkan kondisi di waktu yang akan datang dalam mana perencanaan dan kegiatan yang diputuskan akan dilaksanakan, saat periode sekarang pada saat rencana dibuat. Dalam melakukakan perencanaan, ada beberapa aspek yang harus diperhatikan, antara lain sebagai berikut:

a. Hasil yang ingin dicapai.

b. Apa yang akan dilakukan.

c. Waktu dan skala prioritas

d. Dana (kapital).

Perencanaan dengan segala variasinya ditujukan untuk membantu mencapai tujuan suatu lembaga atau organisasi. Ini merupakan prinsip yang penting, karena fungsi perencanaan harus mendukung fungsi manajemen berikutnya, yaitu fungsi pengorganisasian, fungsi pelaksanaan, dan fungsi pengawasan.

2. Organizing (pengorganisasian) yaitu sebagai sebuah lembaga, Badan Amil Zakat juga harus dikelola secara profesional dan didasarkan atas aturan-aturan keorganisasian. Untuk terwujudnya suatu organisasi/lembaga yang baik, maka perlu dirumuskan beberapa hal di bawah ini:

a. Adanya tujuan yang akan dicapai.

b. Adanya penetapan dan pengelompokan pekerjaan.

c. Adanya wewenang dan tanggung jawab. d. Adanya hubungan satu sama lain.

e. Adanya penetapan orang-orang yang akan melakukan pekerjaan atau tugas-tugas yang diembankan kepadanya.

3. Directing (pelaksanaan) dalam pengelolaan dan pendistribusian zakat terdapat tiga strategi dalam pelaksanaan pengumpulan zakat, yaitu:

a. Pembentukan unit pengumpulan zakat.

b. Pembukaan kounter penerimaan zakat.

c. Pembukaan rekening bank.

Di samping itu, untuk menumbuhkan niat berzakat, baik untuk pegawai institusional pemerintah maupun swasta, dapat melakukan berbagi cara, misalnya:

1. Memberikan wawasan yang benar dan memadai tentang zakat, infaq, sedekah, baik dari epistemologi, terminologi maupun kedudukannya dalam ajaran Islam.

2. Manfaat serta hajat dari zakat, infaq, sedekah, khususnya untuk. pelakunya maupun para mustahiq zakat.

Sedangkan untuk pelaksanaan pendistribusian zakat produktif dapat dikategorikan dalam berapa cara yaitu:

a. Produktif Tradisional

Pendistribusian ini adalah zakat yang diberikan dalam bentuk barang-barang tradisional, di mana dengan menggunakan 
barang-barang tersebut, para mustahik dapat menciptakan suatu usaha, seperti pemberian bantuan ternak kambing, sapi perahan atau untuk membajak sawah, alat pertukangan, mesin jahit, dan sebagainya.

b. Produktif kreatif

Pendistribusian zakat secara produktif kreatif ialah zakat yang diwujudkan dalam bentuk pemberian modal bergulir, baik untuk permodalan proyek sosial, seperti membangun sekolah, sarana kesehatan atau tempat ibadah maupun sebagai modal usaha untuk membantu atau bagi pengembangan usaha para pedagang atau pengusaha kecil.

3. Controlling (pengawasan) dapat didefinisikan sebagai proses untuk menjamin bahwa tujuan- tujuan organisasi dan manajemen tercapai. Ini berkenaan dengan cara-cara membuat kegiatan- kegiatan sesuai dengan yang telah direncanakan sebelumnya. Pengertian ini menunjukkan adanya hubungan yang erat antara perencanaan dan pengawasan. Oleh karena itu, pengawasan mempunyai peranan atau kedudukan yang sangat penting dalam manajemen, karena mempunyai fungsi untuk menguji apakah pelaksanaan kerja itu teratur, tertib, terarah atau tidak. ${ }^{32}$
A. Efektifitas Pemberian Zakat Sebagai Modal Usaha di Badan Amil Zakat (BAZNAS) Kota Bengkulu

Badan Amil Zakat Nasional di Bengkulu bertugas menghimpun, mengumpulkan dan menyalurkan zakat, infak dan sedekah dari para muzakki kepada para mustahik. Dalam proses penghimpunan, pengumpulan, dan penyaluran zakat di bantu oleh Unit Pengumpul Zakat (UPZ) yang ada di berbagai wilayah, kantor Dinas, Lembaga, dan Desa. Hal ini di dukung oleh Peralihan Undang- undang No. 38 Tahun 1999 Tentang Pengelolaan Zakat, ke Undang-undang No. 23 Tahun 2011 Tentang Pengelolaan Zakat ${ }^{33}$ yakni UPZUPZ yang ada di Dinas, Lembaga Desa, Masjid, harus mempunyai Surat Keputusan (SK) dari BAZNAS hal ini agar UPZ diakui oleh BAZNAS. ${ }^{34}$

Jadi apabila lembaga UPZ- UPZ tersebut sudah diberi SK maka akan mempermudah BAZNAS dalam menghitung dan merekap jumlah zakat, infak dan sedekah yang masuk. Serta bagi para UPZ berhak untuk mengumpulkan, menyalurkan zakat, infak dan sedekah setelah melaporkan terlebih dahulu kepada BAZNAS.

${ }^{33}$ Undang- undang No. 38 Tahun 1999 dan Undang-undang No. 23 Tahun 2011

${ }^{34}$ Hasil wawancara kepada bapak Drs. Saidina Aksar bidang pengumpulan data pada tanggal 29 Agustus pukul 10.00 wib 2019

\footnotetext{
${ }^{32}$ Fakhruddin. h, 29-38
} 
Untuk mengtahui kegunaan dan efektifitas BAZNAS dalam menjalankan tugas sebagai amil adalah dengan koordinasi kepada UPZ, atau kepada KUA Kecamatan untuk mendata siapa saja calon muzakki. setelah mendapatkan data calon muzakki pihak BAZNAS menindak lanjuti untuk proses penyaluranya yang akan diberikan kepada penerima bagian ekonomi kreatrif yang mana sudah menyerahkan pengajuan danadana zakat khusunya untuk pengembangan zakat produktif.

Dari beberapa tujuan efektivitas diatas maka dapat dipahami bahwa yang menjadi indikator efektivitas ialah tercapainya tujuan dari sebuah lembaga, maka kembali ke tujuan dari distribusi zakat produktif yang dilaksanakan oleh BAZNAS ialah agar dapat merubah mustahik zakat muzaki. ${ }^{35}$

Pendistribusian adalah tata cara atau tindakan penyaluran barang atau jasa ke pihak lain dengan tujuan tertentu. Jadi, pendistribusian zakat adalah penyaluran zakat kepada orang yang berhak menerima (mustahik) baik secara konsumtif ataupun produktif dengan tujuan agar kesejahteraan mustahik dapat meningkatkan perekonomian masyarakat yang mendapatkan dana zakat produktif. Sasaran mustahik zakat sudah ditentukan

${ }^{35}$ Hasil wawancara kepada bapak Drs. Saidina Aksar bidang pengumpulan data pada tanggal 29 240 sebagimana disebutkan dalam surat atTaubah ayat 60 yaitu delapan golongan.

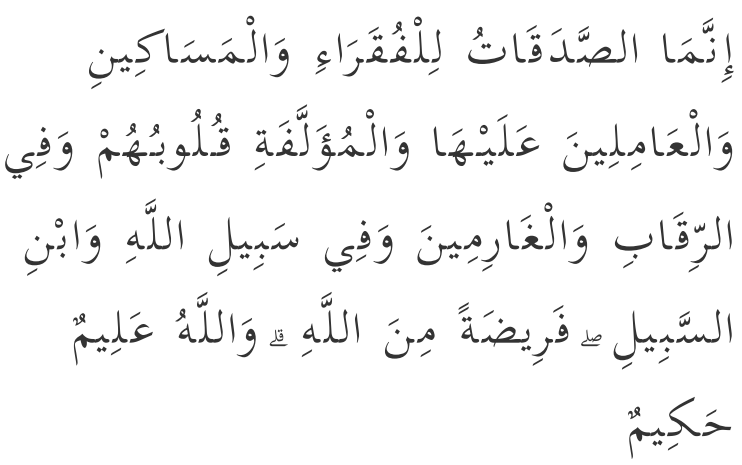

Artinya

Sesungguhnya zakat-zakat itu, hanyalah untuk orang-orang fakir, orangorang miskin, pengurus-pengurus zakat, Para mu'allaf yang dibujuk hatinya, untuk (memerdekakan) budak, orang-orang yang berhutang, untuk jalan Allah dan untuk mereka yuang sedang dalam perjalanan, sebagai suatu ketetapan yang diwajibkan Allah, dan Allah Maha mengetahui lagi Maha Bijaksana(QS AtTaubah 60) ${ }^{36}$

Dari ayat tersebut cukup jelas bahwa pendistribusian zakat harus sampai kepada delapan golongan yang telah disebutkan, walaupun dalam perkembangannya mengalami perluasan makna karena menyesuaikan dengan perkembangan situasi dan kondisi modern.

Model pendistribusian harta zakat oleh muzaki ada dua cara yaitu dapat dilakukan secara langsung kepada mustahik atau lewat lembaga zakat yang nantinya akan disalurkan kepada mustahik. $^{14}$ Distribusi zakat terkadang hanya bersirkulasi pada suatu tempat tertentu, ketika zakat tidak dikelola secara

\footnotetext{
${ }^{36}$ Alquran dan terjemahannya, Depag 2002
} 
keseimbangan dan diberikan langsung oleh si pemberi zakat (Muzaki) kepada mustahik. Hal ini salah satu faktor penyebabnya karena kurang adanya lembaga zakat yang profesional yang menyampaikan dana zakat tersebut kepada umat yang membutuhkan juga berimplikasi pada peningkatan kesejahteraan masyarakat.

Untuk mencapai hasil yang maksimal, efektif dan efisien serta tercapainya tujuan dan sasaran zakat, maka pendayagunaan alokasi dana zakat dapat digolongkan kedalam empat katagori, sebagai berikut:

a. Bersifat konsumtif tradisional yaitu zakat dibagikan kepada mustahik untuk dimanfaatkan secara langsung, seperti zakat fitrah yang diberikan kepada fakir miskin untuk memenuhi kebutuhan sehari-hari atau zakat harta yang dibagikan kepada para korban bencana alam.

b. Penyaluran bersifat konsumtif kreatif yaitu zakat diwujudkan dalam bentuk lain dari barangnya semula, seperti diberikan dalam bentuk alatalat sekolah atau beasiswa.

c. Penyaluran dalam bentuk produktif tradisional yaitu zakat yang diberikan dalam bentuk barang produktif seperti kambing, sapi, alat cukur, dan sebagainya. Pemberian dalam bentuk alat produksi tersebut diharapkan dapat menciptakan suatu usaha yang membuka lapangan kerja bagi fakir miskin.

d. Penyaluran dalam bentuk produktif kreatif yaitu zakat diberikan dalam bentuk pemodalan baik untuk membangun proyek sosial atau menambah modal pedagang atau pengusaha kecil. ${ }^{37}$

Kemudian untuk muzakki tidak harus membayar langsung lewat BAZNAS maupun UPZ akan tetapi untuk zakat profesi misalnya, bisa melalui Bank dan BAZNAS mempunyai Rekening untuk menghimpun dana zakat tersebut. Untuk mustahik zakat BASNAS mempunyai kebijakan bahwa fakir, miskin, amil dan sabilillah yang mendapatkan dana zakat, dikarenakan riqab, gharim, muallaf dan musaffir jarang ditemukannya di Bengkulu, akan tetapi riqab, gharim, muallaf dan musaffir tetap mendapatkan perhitungan dana. Dan dana perhitungan tersebut tetap dibagikan kepada fakir miskin dan masyarakat membutuhkan dalam hal perubahan ekonomi masyarakat khususnya dalam penerimaan zakat produktif.

Dalam rangka mencapai efektivitas kerja atau efisiensi haruslah dipenuhi

37 Muhammad Daud Ali, Sistem Ekonomi Islam; Zakat dan Wakaf (Jakarta: Universitas Indonesia, 1988), h. 62-63 
syarat- syarat ataupun ukuran sebagai berikut: ${ }^{38}$

a. Kegunaan, yakni agar berguna bagi manajemen dalam pelaksanaan fungsi- fungsinya yang luas, suatu rencana harus fleksibel, stabil, berkesinambungan, dan sederhana.

b. Ketepatan dan objektifitas, maksudnya semua rencana harus dievaluasi untuk mengetahui apakah jelas, ringkas, nyata dan akurat.

Sedangkan untuk mengetahui tolok ukur ruang lingkup, efektifitas biaya akuntabilitasnya dan ketepatan waktu adalah, setelah dana dari muzakki terkumpul maka, BAZNAS segera merapatkan untuk proses pentasyarufanya, setelah rapat BAZNAS mengirim surat melalui KUA untuk pendataan mustahik setelah data tekumpul BAZNAS menindak lanjuti untuk proses pentasyarufannya. Pentasyarufan ZIS melalui pengumpulan dari pihak mustahik, jadi mustahik langsung mendapatkan zakat tanpa melalui perantara, kemudian setelah proses pentasyarufan kepada mustahik pada akhir tahun BAZNAS membuat Laporan Pertanggung Jawaban (LPJ). Dengan adanya bantuan dari UPZ secara biaya dapat meminimalisir biaya pengeluaran untuk transport mendatangi muzakki. jadi

38 Hani Handoko, Manajemen, Yogyakarta: BPFE, 2003), h. 103-105 biaya transport tersebut bisa ditambah untuk keperluan mustahik. Untuk ketepatan waktu dalam pentasayarufan untuk zakat akhir tahun atau pada akhir Bulan Ramadhan, sednagkan pentasyrufan infak dan sedekah tergantung dari mustahik, karena penyaluran infak/ sedekah bermacam- macam. ${ }^{39}$

c. Ruang lingkup, yakni perlu memperhatikan prinsip-prinsip kelengkapan, kepaduan, dan konsistensi.

d. Efektivitas biaya, dalam hal ini efektivitas biaya menyangkut waktu, usaha, dan aliran emosional.

e. Akuntabilitas, terdapat dua aspek akuntabilitas, pertama tanggung jawab atas perlaksanaan, kedua tanggung jawab atas implementasinnya.

f. Ketepatan waktu, yakni suatu perencanaan, perubahan-perubahan yamg terjadi sangat cepat akan dapat menyebabkan rencana tidak tepat atau sesuai untuk berbagai perbedaan waktu. $^{40}$

Kaitanya dengan efektivitas dalam meningkatkan jumlah zakat, infak dan sedekah, upaya BAZNAS dalam mengumpulkan adalah sosialisasi kepada masyarakat, agar masyarakat sadar

${ }^{39}$ Hasil wawancara kepada bapak Drs. Saidina Aksar bidang pengumpulan data pada tanggal 29 Agustus pukul 10.00 wib 2019

40 Hani Handoko, Manajemen, Yogyakarta: BPFE, 2003), h. 103-105 
membayar ZIS nya. Kemudian untuk lebih efektif BAZNAS melakukan koordinasi kepada para UPZ yang ada di Bengkulu untuk membantu mensosialisasikan kepada rekan dan masyarakat sekitar untuk menumbuhkan kesadaran mereka dalam membayar ZIS untuk mengembangkan perekonomian masyarakat yeng membutuhkannya terutama masyarakat yang ingin berusaha dalam meningkatkan ekonomi.

Dalam melakukan sosialisasi, UPZ yang ada di Dinas, Lembaga, Musholla dan lain-lain mengirim surat permohonan sosialisasi ke BAZNAS dari BAZNAS menindak lanjuti dan begitu seterusnya dalam pendistribusian dana zakat yang akan disalurkan kepada mazyarakat yang berhak menerimannya.

Pengelolaan zakat ini bertujuan meningkatkan efektivitas, efisiensi dan meningkatkan manfaat zakat untuk mewujudkan kesejahteraan masyarakat dan penanggulangan kemiskinan. ${ }^{41}$

Selain itu keberadaan BAZNAS di masyarakat terutama masyarakat Bengkulu sangat efektif dalam mengumpulkan dan menyalurkan zakat, infak dan sedekah. Karena tiap UPZ sekarang diberikan SK supaya terdapat hukum yang jelas, baik hukum positif maupun syah secara syar'i. setelah UPZ diberikan SK masing- masing

41 Pasal 3, Undang- Undang No 23 Tahun 2011 Tentang Pengelolaan Zakat akan mempermudah pelaporan dana ZIS kepada BAZNAS dan BAZNAS megetahui secara menyeluruh sejauh mana peningkatan ZIS dan terbukti ada peningkatan yang signifikan terhadap peroleahan jumlah ZIS.

Seperti upaya yang dilakukan oleh beberapa UPZ yang ikut serta membantu BAZNAS dalam meningkatkan jumlah perolehan zakat, infak dan sedekah. Upaya UPZ adalah tetap dengan cara sosialisasi kepada masyarakat khususnya caloncalon muzakki dalam mengembangkan ekonomi khususnya (usaha ekonomi kreatif). Selain itu saling memberitahukan kepada teman bahwa harta yang kita miliki hanya titipan dari Allah, yang tidak semuanya milik kita tetapi ada hak orang lain yang ada pada harta kita. Dengan adanya efektifitas tersebut didukung oleh data yang ada pada BAZNAS diketahui bahwa hampir setiap tahun ada peningkatan antara zakat, infak dan sedekah tiap tahunnya. Untuk perolehan peningkatan jumlah zakat mal/ profesi setiap tahun mengalami peningkatan.

BAZNAS mempunyai kebijakan mustahik zakat sebanyak 4 asnaf yakni fakir, miskin, sabilillah, dan amil, bahwa 4 asnaf yang lain (ibnu sabil, gharim, riqab, muallaf) meskipun tidak mendapat zakat tetapi tetap ada perhitungan besarnya zakat. Perhitungan dan pembagian zakat asnaf yang lain tersebut 
Dwi Putra Jaya dan Hurairah: Zakat Produktif Sebagai Modal Usaha Masyarakat (Studi Badan Amil Zakat Kota Bengkulu)

diberikan kepada asnaf fakir dan miskin.

Sedangkan mustahik dari infak dan sedekah penyaluranya pada :

a. Yatim/ dhuafa

b. Bencana alam, Bedah rumah, Pengobatan

c. Tempat ibadah, Syiar agama

d. Usaha Produktif

e. Beasiswa

f. Pembinaan keagamaan

g. Kegiatan pendidikan Islam

h. wakaf

i. Operasioanal.

BAZNAS mengakui bahwa ada peningkatan kesejahteraan ekonomi masyarakat. Terbukti mustahik yang mendapat pinjaman dari BAZNAS tidak sekali meminjamnya bahkan berkali-kali dan mustahik teratur mengembalikan dana pinjaman tersebut.. Penyaluran dana zakat rata-rata bagi mustahik digunakan untuk kebutuhan konsumtif sedangkan dana infak/sedekah untuk kebutuhan konsumtif, sosial dan produktif. Seperti penyaluran dana infak/ sedekah salah satunya untuk memberikan pinjaman tanpa bunga kepada para usaha produktif. Hal ini dapat mempengaruhi peningkatan kesejahteraan ekonomi mustahik. ${ }^{42}$

Secara ekonomi, zakat dapat berfungsi sebagai salah satu instrument untuk mengentaskan kemiskinan,

42 Hasil wawancara kepada bapak Drs. Saidina Aksar bidang pengumpulan data pada tanggal 29 Agustus pukul 10.00 wib 2019 memeratakan pendapatan, dan mempersempit kesenjangan antara kelompok kaya dan miskin. Zakat bukanlah ajaran untuk memeras orang kaya, secara empirik, tidak ada bukti seseorang yang kaya berubah menjadi miskin hanya karena mengeluarkan zakat. Jenis harta, jumlah minimal (nisab) harta yang wajib dizakati, jangka waktu (haul), dan kadar zakat dari setiap harta yang wajib dizakati telah ditentukan sedemikian rupa sehingga, secara nominal, tidak mengganggu atau merugikan si pemilik harta tersebut. ${ }^{43}$

Sebagai buktinya adalah peneliti mendatangi beberapa mustahik yang bertemu di kantor BAZNAS Kota Bengkulu, baik mustahik zakat dan infak/ sedekah. Menurut beberapa mustahik tersebut ada peningkatan dalam memenuhi kebutuhannya, baik konsumtif dan produktif. Untuk zakat fitrah dan zakat mal / profesi, ada peningkatan dalam membantu kebutuhan secara konsumtif. Sedangkan infak / sedekah dapat membantu kebutuhan konsumtif, sosial dan produktif. Peningkatan kesejahteraan selain membantu kebutuhan konsumtif dan produktif bantuan bedah rumah yang ada pada BAZNAS juga membantu dalam kesejahteraan hidup keluarga yang mendapatkan bantuan bedah rumah.

${ }^{43}$ M. Djamal, Membangun Ekonomi ...,h.98 
Dalam Teori Ridwan dana yang bersumber dari infak juga memiliki potensi yang cukup besar dan dapat dioptimalkan lagi pengelolaannya baik dari segi penghimpunan maupun pendayagunaannya untuk kegiatankegiatan yang produktif bagi pembangunan umat atau kesejahteraan masyarakat. $^{44}$

Dalam pembahasan penyaluran dana infak/sedekah untuk pinjaman usaha produktif hanya sebagai pinjaman, seharusnya itu diberikan tidak untuk dikembalikan. Pihak BAZNAS mempunyai alasan kenapa dana tersebut sebagai dana pinjaman, tidak diberikan cuma-cuma karena takutnya tidak produktif dan kalau mustahik meminjam maka dia merasa mempunyai tanggungan untuk mengembalikan, selain itu dana yang sudah kembali diputar lagi. Akan tetapi penyaluran dana usaha produktif tidak sebanding dengan penyaluran terhadap fakir miskin dan amil, seharusnya Usaha produktiflah yang penyaluranya diperbanyak karena untuk memandirikan mustahik agar tidak hanya sebagai mustahik konsumtif, tetapi juga mustahik produktif. Kemudian untuk bisa lebih maksimal peminjaman dana untuk usaha produktif lebih baik ada pelatihan dan pendampingan agar bisa lebih

44 Andi Riswan Ritonga, Analisis FaktorFaktor..., h. 43 meningkatkan kesejahteraan ekonomi masyarakat Bengkulu. ${ }^{45}$

Berbeda dengan teori dari Gus Arifin Sedekah adalah pemberian sesuatu dari seseorang kepada orang lain karena ingin mendapatkan pahala dari Allah. Definisi lain sedekah adalah setiap amal kebaikan secara umum baik materiil maupun non-meteriil. ${ }^{46}$

Jadi, dengan adanya pemberian zakat, infak sedekah kepada para mustahik dapat memberikan pengaruh terhadap peningkatan kesejahteraan ekonomi baik secara konsumtif produktif dan sosial.

Hasil penelitian yang menunjukan adanya peningkatan kesejahteraan mustahik didukung oleh Hasrullah Rahim $^{47}$, hasil penelitian tersebut adalah Pendistribusian zakat yang dilakukan BAZNAS Kota Bengkulu ada dua macam. Pertama, pendistribusian secara konsumtif maksudnya penyaluran dana zakat yang langsung dibutuhkan oleh mustahiq. Kedua, pendistribusian secara produktif maksudnya pemberian dana zakat berupa bantuan-bantuan produktif untuk meningkatkan taraf hidup mereka. Untuk pendistribusian ditetapkan atas dua prioritas.

${ }^{45}$ Hasil wawancara kepada bapak Drs. Saidina Aksar bidang pengumpulan data pada tanggal 29 Agustus pukul 10.00 wib 2019

${ }^{46}$ Gus Arifin, Zakat Infaq, Sedekah...., h.189

47 Hasrullah Rahim, Efektivitas Pelaksanaan...,h. 78-79 
Dwi Putra Jaya dan Hurairah: Zakat Produktif Sebagai Modal Usaha Masyarakat (Studi Badan Amil Zakat Kota Bengkulu)

Prioritas pertama terdiri dari fakir, miskin, amil dan muallaf sedangkan prioritas kedua terdiri dari gharim, fisabilillah dan ibnu sabil. Dalam pengumpulan, pendistribusian dan penyaluran zakat, pihak BAZNAS ada yang mempunyai kendala dan ada pula yang tidak mempunyai kendala.

Hasil penelitian tentang kendalakendala dalam mengumpulkan zakat, infaq dan sedekah, didukung oleh studi Abdul Kholiq Syafa'at, ${ }^{48}$ Hasil survei yang telah dilakukan terhadap kendala yang dihadapi oleh Badan Amil Zakat Kabupaten Banyuwangi adalah kurangnya sumber daya yang berpengalaman.

Hal ini didukung oleh penelitian dari Andi Riswan Ritongga, ${ }^{49}$ BAZDASU sebagai publik/nirlaba milik pemerintah, yang rentan akan Kepercayaan publik, juga memiliki kendala-kendala dalam pengumpulan dana ZIS. Kendala-kendala tersebut terdapat dari pihak internal maupun pihak eskternal. Kendala eksternal tersebut diantaranya ialah: 1. Keberadaan sumber daya manusia (SDM) yang kurang berkompetensi dalam mengelola

48 Abdul Kholiq Amrullah, Potensi Zakat, Infaq, dan Sedekah pada Badan Amil Zakat Nasioanal di Kabupaten Banyuwangi, (Surabaya: UIN Surabaya), h. 16, dalam ttp://eprints.uinsby.ac.id/195/1/Executiive\%20sum mary\%20Dr.\%20H.\%20Abdul\%20Kholi q\%20Syafa\%E2\%80\%99at,\%20MA.pdf, diakses pada 31 Mei 2016

49 Andi Riswan Ritonga, Analisis Faktor-
BAZDASU 2. Keterbatasan alokasi atau pos dana untuk promosi dan sosialisasi ZIS yang dimiliki BAZDASU 3. Belum adanya Peraturan Daerah (PERDA) yang kuat dan mengikat masyarakat untuk membayar dana ZIS melalui BAZDASU. Untuk kendala eksternal ialah: 1. Kurangnya kepercayaan masyarakat terhadap BAZDASU. 2. Masih melekatnya budaya masyarakat, dalam hal ini sebagai muzakki yang membayar zakat secara langsung kepada Mustahik. 3. Masih dominanya perilaku masyarakat Muslim yang mengutamakan kewajiban membayar pajak dibandingkan kewajiban membayar zakat, sehingga pajak lebih menjadi prioritas, yang menjadikan zakat sebagai beban ganda bagi masyarakat.

B. Penerapan Pemberian Zakat Sebagai Modal Usaha di Badan Amil Zakat (BAZNAS) Kota Bengkulu

Berdasarkan program BAZNAS Kota Bengkulu maka untuk merealisasi program tersebut, BAZNAS melakukan sosialisasi untuk menarik minat dalam berzakat, yaitu:

Selanjutnya Bapak Safrizal S.E mengatakan cara sosialisasi BAZNAS Kota Bengkulu yaitu ${ }^{50}$ :

a. Menyebarkan brosur ke perumahanperumahan,

b. Menyampaikan ceramah-ceramah tentang zakat kepada masyarakat,

${ }^{50}$ Hasil wawancara kepada bapak Safrizal S.E sebagai wakil ketua II BAZNAS Kota Bengkulu pada tanggal 29 Agustus pukul 15.00 wib 2019 
c. Bersosialisasi ke kantor-kantor, sekolah-sekolah, badan-badan, dan instansi-instansi yang terkait.

d. Melalui elektronik seperti TV, koran, Radio, dan melalui media sosial.

Menurut Bapak Dsr. Saidina Aksar selaku Wakil Ketua I BAZNAS Kota Bengkulu, mengatakan bahwa terdapat 6 cara sosialisasi yaitu:

a. Menggunakan metode ceramah maksudnya mengajak masyarakat Kota Bengkulu untuk menyalurkan zakatnya ke lembaga pengelola zakat.

b. Membuat brosur bertujuan untuk memperkenalkan kepada masyarakat tentang suatu lembaga zakat.

c. Memasang baliho untuk memudahkan masyarakat mengetahui lokasi lembaga tersebut.

d. Mengadakan sosialisasi pada Dinas Instansi, Kantor, Badan Perbadan, Sekolah, dll. Untuk menghimbau para karyawan agar bersedia menyalurkan zakatnya pada lembaga zakat.

e. Menggunakan media massa seperti koran, maksudnya untuk menghimbau para muzakki untuk menyalurkan zakatnya.

f. Menggunakan media elektronik $\begin{array}{lll}\text { seperti } & \text { TV. Untuk }\end{array}$ memperkenalkan tentang suatu lembaga zakat.

Selanjutnya Bapak Dsr. Saidina Aksar mengatakan sosialisasi tersebut sudah terlaksana dengan baik. dapat diketahui bahwa ceramah yang dilakukan oleh BAZNAS ini sudah hampir di wilayah kota semua, tetapi masih banyak juga masyarakat yang belum mengetahui tentang lembaga Baznas tersebut, sehingga masyarakat menyalurkan zakatnya sendiri kepada mustahik. ${ }^{51}$

Sama halnya dengan Bapak Safrizal S.E mengatakan sosialisasi BAZNAS yaitu $^{52}$ :

a. Melakukan sosialisasi kepada SKPD-SKPD， OPD-OPD， Badanbadan, Lembaga-Lembaga, BankBank dan bermacam-macam.

b. Melalui media seperti: koran, TV dan lain-lain

c. Melalui khutbah zakat yang nantinya dibagi sama Da"i zakat.

Dari hasil wawancara penulis diatas mengenai sosialisasi BAZNAS bahwa sosialisasinya itu hampir sama disini BAZNAS lebih menggunakan metode ceramah karena kebanyakan basijnya itu hampir ustad semua jadi, cara mereka melalui metode ceramah itu sangat baik. Selanjutnya ada beberapa pelaksanaan sosialisasi dalam menjalankan program

\footnotetext{
${ }^{51}$ Hasil wawancara kepada bapak Dsr. Saidina Aksar pada tanggal 29 Agustus pukul 10.00 wib 2019

${ }^{52}$ Hasil wawancara kepada bapak Safrizal S.E pada tanggal 30 Agustus pukul 10.00 wib 2019
} 
tersebut diantaranya:

Menurut pendapat Dsr. Saidina Aksar selaku wakil Ketua I BAZNAS Kota Bengkulu mengatakan bahwa ${ }^{53}$ :

Telah mengajak seluruh masyarakat Kota Bengkulu agar tidak ragu dalam memberikan zakatnya melalui BAZNAS. Dan juga menyampaikan ceramahnya mengenai zakat yang mana zakat itu merupakan perantara keagamaan yang bertujuan untuk meningkatkan keadilan dan kesejahteraan masyarakat, khususnya masyarakat Kota Bengkulu. Beliau berharap agar seluruh masyarakat Kota Bengkulu dapat memberikan zakatnya melalui badan yang resmi sebagaimana halnya BAZNAS, Agar bisa di kelola dengan baik sehingga tidak terjadi tumpang tindih terhadap penyaluran zakat kepada masyarakat.

Sama halnya dengan Safrizal SE selaku bidang pendistribusian mengatakan bahwa sosialisasi tersebut yaitu ${ }^{54}$ :

Ketika terjun kelapangan untuk menjemput zakat bidang pengumpulan wakil ketua I terlebih dahulu melakukan strategi salah satunya bidang pengumpulan yaitu sosialisasi ke dinas-dinas, instansiinstansi, kantor- kantor terkait di wilayah Kota Bengkulu, ketika selesai sosialisasi kemudian di follow up dan mereka siap

\footnotetext{
${ }^{53}$ Hasil wawancara kepada bapak Dsr.Saidina Aksar pada tanggal 20 Agustus pukul $10.00 \mathrm{wib}$ 2019

${ }^{54}$ Hasil wawancara kepada Safrizal SE pada 248
}

untuk membuat UPZ jenis dari Unit Pengumpulan Zakat dan menyatakan bahwa siap di jemput setiap bulan zakatnya. untuk masyarakat umum itu berupa ceramahceramah, mengisi hari peringatan Islam. Jadi, wakil ketua I dan wakil ketua II dalam acara itu mereka beriniziatif melakukan secara tidak langsung syiar terkait dengan profil BAZNAS Kota Bengkulu dan tentang perhimpunannya, dan juga mengajak masyarakatnya untuk berzakat berinfak ke badan yang resmi yaitu Badan Amil Zakat.

Selanjutnya Drs. Saidina Aksar selaku bidang pengumpulan mengatakan bahwa Sosialisasi yang dilakukan dilapangan oleh BAZNAS dalam menarik minat masyarakat dalam berzakat antara lain ${ }^{55}$ :

1. Sosialisasi sesuai jadwal,

2. Melampirkan surat terlebih dahulu, kalau ada balasan baru di konfirmasi.

3. Kemudian sms kepada InstansiInstansi yang bersangkutan, sebelum menjemput dana zakat kami jelaskan dulu mengenai zakat, setelah itu pihak BAZNAS menanyakan kapan dana zakatnya bisa diambil. Setelah di sms kadang orangnya tidak ada di kantor, kemudian susah di jumpai.

\footnotetext{
${ }^{55}$ Hasil wawancara kepada Drs. Saidina Aksar pada tanggal 29 Agustus pukul 10.00 wib 2019
} 
4. Membagikan brosur ketika pimpinannya sedang melakukan ceramah itu dibagikan sama jamaahnya, ketika sedang pendistribusian itu di lampirkan, ketika ibu-ibu sedang majlis taqlim di mesjid itu juga di bagikan brosurnya.

5. Kemudian ada juga melalui khutbah yang melakukannya itu perpimpinan, stafnya Cuma mandampingi misalnya ada sosialisasi kerumah sakit kota sebagian staffnya ada yang ikut dan ada yang tinggal.

Dari hasil wawancara diatas bahwa pihak BAZNAS lebih cenderung sosialisasinya ke kantor-kantor, instansiinstansi ataupun Badan-badan yang terkait. tetapi untuk masyarakat umum pihak BAZNAS masih kurang dalam melakukan sosialisasinya. Seperti itulah salah satu strategi yang dilakukan lembaga BAZNAS dalam menghimpun dana zakat agar masyarakat mau berzakat. Sosialisasi tersebut sudah terlaksana namun belum efektif, hanya $60 \%$ yang sudah berjalan saat ini. Dari pendapat Al-Jihad diatas Penulis menyimpulkan bahwa sosialisasi tersebut seharusnya sudah lebih efektif dan bisa di kembangkan agar masyarakat lebih tau tentang lembaga tersebut. sehingga Program BAZNAS bisa berjalan semua.
Sejauh yang penulis ketahui bahwa program-program BAZNAS Kota Bengkulu sudah berjalan dan masyarakat sudah menyerap sebagaimana mestinya seperti: Kota Bengkulu Makmur, Kota Bengkulu Taqwa, Kota Bengkulu Cerdas, Kota Bengkulu Sehat, dan Bantuan Dhu'affa. Yang belum terlaksana itu adalah Bedah Rumah Dhu'eaffa dan Bantuan Bencana Alam/Kemanusiaan dan khusnya pembagian kepada masyarakat yang menjalankan visi dam misi BAZNAS Kota Bengkulu dalam hal ekonomi kreatif.

Berdasarkan pererapan yang disarasan oleh masyarakat dalam hal peningkatan ekonomi pada masyarakat yang melalui sosialisasi yang sudah dilakukan oleh BAZNAS Kota Bengkulu untuk meningkatkan minat masyarakat dalam pengembangan ekonomi kreatif, hasilnya sudah menuju signifikan dalam meningkatkan ekonomi masyarakat dalam bidang ekonomi keatif.

\section{Kendala BAZNAS Kota Bengkulu} Untuk Meningkatkan Minat Masyarakat

\section{Dalam Berzakat}

Ada beberapa kendala yang di alami BAZNAS dalam menjalankan sosialisasi, yaitu:

Dari hasil wawancara dengan Drs. Saidina Aksar mengatakan kendala yang dialami di lapangan sewaktu sosialisasi 
Dwi Putra Jaya dan Hurairah: Zakat Produktif Sebagai Modal Usaha Masyarakat (Studi Badan Amil Zakat Kota Bengkulu)

sebagai berikut ${ }^{56}$ :

1. Dilihat dari pihak kantor ataupun dari masyarakat ada yang belum banyak pemahamannya mengenai lembaga zakat atau kebiasaannya yang menyalurkan zakatnya kepada keluarga terdekat, Sehingga membuat mereka tidak menyalurkan zakatnya ke lembaga zakat.

2. Ketika mau menjemput dana zakat di kantor-kantor kebanyakan ketika di datangi mereka tidak ada di kantor atau sedang rapat, dan juga ketika pimpinan melakukan khutbah sebagian jamaahnya ada yang mendengarkan ada juga yang tidak, ketika membagikan brosur banyak yang menolak, atau mereka ambil tapi kemudian mereka buang.

\section{A. Kesimpulan}

Dari penjelasan yang dikemukakan dalam tulisan ini, dapat penulis simpulkan sebagai berikut:

1. Dalam efektifitas dana zakat yang diterima masyarakat mereka yang memang pantas untuk dibantu, tidak secara keseluruhan delapan asnaf mendapatkan bantuan zakat profesi, yang mendapatkannya fakir, miskin, fisabilillah, mu'allaf dan musafir, serta zakat produktif untuk pedagang kecil dalam memajukan usahanya, dan

${ }^{56}$ Hasil wawancara kepada bapak Drs. Saidina Aksar sebagai wakil ketua I BAZNAS Kota Bengkulu pada tanggal 29 Agustus pukul $11.00 \mathrm{wib}$ 2019 program beasiswa bagi pelajar maupun mahasiswa agar dapat melanjutkan pendidikannya khususnya meningkatkan ekonomi dalam keluarga.

2. Distribusi zakat produktif yang diberikan oleh BAZNAS Kota Bengkulu melalui "Program" kepada mustahik di daerah Kota Bengkulu dapat meningkatkan dua faktor kesejahteraan Mustahik. Sehingga zakat produktif yang didistribusikan oleh BAZNAS Kota Bengkulu dinilai sudah efektif dalam meningkatkan kesejahteraan Mustahik, ini dibuktikan dengan meningkatnya pendapatan mustahik.

\section{B. Saran}

1. BAZNAS kota Bengkulu perlu meningkatkan sosialisasi dan promosi, agar masyarakat lebih banyak tahu tentang, keberadaan lembaga tersebut sehingga mereka lebih mudah untuk menyalurkan zakatnya.

2. Agar dapat mengembangan kegiatan ekonomi maupun maupun lainnya. Dan perlu adanya penelitian lebih lanjut untuk kajian-kajian yang lebih mendalam secara terus menerus tentang pendayagunaan dana zakat yang digunakan untuk pemberdayaan mustahik, sebab dengan adanya program kegiatan khususnya masyarakat Kota Bengkulu. 


\section{Pustaka Acuan}

Abu Bakar Muhammad (Penerjemah)

Terjemahan Subulus Salam II.

Ahmad Rofiq, "Fiqih Kontekstual dari Normatif

ke Pemaknaan Sosial”, (Yogyakarta:

Pustaka Pelajar, 2004),

Ali Yafie, "Menggagas Fiqih Sosial",

(Bandung: Mizan, 1994),

Asnaini, S.Ag, M.ag, Zakat Produktif dalam

Persfektif Hukum Islam, Yogyakarta:

Pustaka Pelajar, 2008, cetakan ke-1,

Azwar Karim, Sejarah Pemikiran Ekonomi

Islam, Jakarta: PT. Raja Grafindo

Persada,2004

Didin Hafiduddin, "Dakwah Aktual”, (Jakarta:

Gema Insani Press, 2001),

Didin Hafiduddin, "Zakat dalam Perekonomian

Modern”, (Jakarta: Gema Insani Press, 2002),

El-Madani, Fiqh Zakat Lengkap, Yogyakarta: Diva Press, 2013

Fahruddin, Fiqh dan Manajemen Zakat Indonesia, Malang: UIN Malang Press, 2008 , cet- 1 ,

Ilyas Supena dan Darmuin, Manajemen

Zakat, Semarang: Walisongo Press, 2009 ,

Joyce M. Hawkins, Kamus Dwi Bahasa Inggris- Indonesia, Indonesia-Inggris, Exford: Erlangga,1996,

M. Arif Mufraini, Akuntansi dan Manajemen Zakat, Jakarta: Kencana Prenada Media Group, 2006
M. Ali Hasan, (Zakat Pajak Asuransi dan Lembaga Keuangan), (Jakarta: Raja Grafindo Persada, 1996),

M. Mutawalli Sya'rawi, "Islam antara Kapitalisme dan Komunisme”, (Jakarta: Gema Insani Press, 1992),

Muhammad Daud ali, Sistem Ekonomi Islam; Zakat dan Wakaf, Jakarta: Universitas Indonesia, 1988

Mursyidi, Akuntansi Zakat Kontemporer", Bandung : PT. Remaja Rosda Karya, 2003 ,

Qodri Azizy, "Membangun Fondasi Ekonomi Umat", (Yogyakarta: Pustaka Pelajar, 2004),

Soeratno dan Lincolin Arsyad, "Metode Penelitian”, (Yogyakarta: Unit Penerbit dan Percetakan AMP YKPN, 1999),

Suharsimi Arikunto, "Prosedur Penelitian Suatu Pendekatan Praktek”,( Jakarta: Rineka Cipta, 1993),

Sukandarrumidi, "Metode Penelitian Petunjuk Praktis Untuk Peneliti Pemula”,(Yogyakarta: Gajah Mada University Press, 2002),

Sumber : Departemen Dalam Negeri RI, Data Wilayah Administrasi Pemerintahan. Pdf - $\quad$ http://id.wikipedia.org/wiki/Daftar Provinsi Indonesia menurut jumlah penduduk pada tahun 2015 di akses pada Tanggal 12 januari 2017

Terjemahan dari Wahbah Al-Zuhaili, Zakat kajian Berbagai Madzhab, Bandung: Remaja Rosda Karya cet ke 6, 2005, 
Yusuf Qadhawi, Musykilah al-Faqr Wakaifa

Aalajaha Al Islam, Beirut:1966,

Yusuf Qardhawi, “Kiat Islam Mengentaskan

Kemiskinan",, terj. Syahril Hakim,

(Jakarta: Gema Insani Press, 1995), 